\title{
NASIONALISME FASHION DAN PEMANTIK CITRA NEGARA DALAM SITUS WWW.DAMNILOVEINDONESIA.COM
}

\author{
Joshua Fernando ${ }^{1}$, Rustono Farady Marta $^{2}$ \\ ${ }^{I}$ Magister Ilmu Komunikasi,Universitas Bunda Mulia, Jakarta, joshuafernandosaty@ gmail.com \\ ${ }^{2}$ Magister Ilmu Komunikasi,Universitas Bunda Mulia, Jakarta, rmarta@bundamulia.ac.id
}

\begin{abstract}
ABSTRAK:
Identitas bangsa dapat mucul dengan adanya simbol yang melekat pada produk/jasa dalam hal ini dunia Fashion. Membangun nilai nasionalisme memang tidak mudah sehingga dibutuhkan adanya kerjasama dari semua pihak termasuk korporat sehingga identitas bangsa tesebut dapat menjadi daya tarik dunia khususnya dalam dunia pariwisata. Damn! I Love Indonesia mewujudkan hal tersebut dengan memasukan unsur nasionalisme dalam setiap produk fashionnya. Penelitian ini melihat bagaimana konstruksi makna nasionalisme yang dibangun dalam produk fashion dilihat dari konten press release website korporat www.damniloveindonesia.com. Penelitian ini menggunakan metode penelitian kualitatif secara deskriptif dengan paradigma konstruktivis dan dianalisis melalui Teori Manajemen Kesan sebagai prespektif teori dan diolah secara mendalam mengunakan metode analisis Framing Zhongdang Pan dan Gerald M. Kosicki. Hasil penelitian ini mengungkapkan bahwa website korporat dapat digunakan sebagai sarana informasi CSR yang merepresentasikan nasionalisme dalam produk serta mendorong peran segmentasi anak muda dalam mempromosikan potensi pariwisata melalui citra bangsa yang dibangun dalam simbol dan merk fashion Damn! I Love Indonesia.
\end{abstract}

Kata Kunci: Nasionalisme, Fashion, Cyber CSR, Framing, Pariwisata

ABSTRACT:

National identity can arise with a symbol attached to the product/service in this case the Fashion world. Building the value of nationalism is not easy, so it requires cooperation from all parties, including corporations, so that the identity of the nation can be a world attraction, especially in the world of tourism. Damn! I Love Indonesia embodies this by incorporating elements of nationalism in every fashion product. This study looks at how the construction of the meaning of nationalism built in fashion products is seen from the content of the press release of the corporate website www.damniloveindonesia.com. This research used descriptive qualitative research methods with constructivis paradigm and analyzed through Impression Management Theory as a theoretical perspective and processed in depth using the analysis method of Framing Zhongdang Pan and Gerald M. Kosicki. The results of this study reveal that the corporate website can be used as a CSR information tool that represents nationalism in products and encourages the role of segmentation of young people in promoting tourism potential through the image of the nation built in symbols and fashion brands Damn! I Love Indonesia.

Keywords: Nationalism, Fashion, Cyber CSR, Framing, Tourism

\section{PENDAHULUAN}

Keberadaan website korporat menjadi sangat penting sebagai sarana menampilkan gambar identitas perusahaan mengenai informasi terbaru mengenai perusahaan dan sampai melakukan berbagai tindakan promosi yang dimaksudkan untuk melakukan peningkatan penjualan. Saat ini kegiatan korporat bukan hanya menampilkan visi, misi, identitas, dan penjualan, tetapi sudah menjangkau sampai kepada kegiatan CSR yang dilakukan berbasis kampanye online. 
Semakin besarnya semangat pemerintah Indonesia untuk meningkatkan promosi pariwisata dan meningkat citra negara sebagai poros pariwisata dunia, demam tersebut juga ditangkap oleh para pelaku dunia usaha untuk membuat produk khususnya di bidang fashion yang mengambarkan citra Indonesia di mata dunia. Selain batik sebagai produk fashion yang diakui oleh UNESCO sebagai warisan dunia, Damn! I Love Indonesia turut meramaikan dunia fashion dengan identitas nasionalisme untuk kaum urban khususnya anak muda masa kini.

Damn! I Love Indonesia merupakan salah satu brand lokal yang bergerak dalam wilayah urban dan menggunakan sarana teknologi masa kini melalui website untuk media promosi dan pejualan secara online yang dikelola oleh PT Dinamika Interaktif Laskar Indonesia (perusahaan www.damniloveindonesia.com). Selain melakukan penjualan produk dengan membuka outlet di seluruh Indonesia, pelebaran pasar berbasis online dinilai menjadi cara ampuh untuk mempelebar pasar lebih luas lagi.

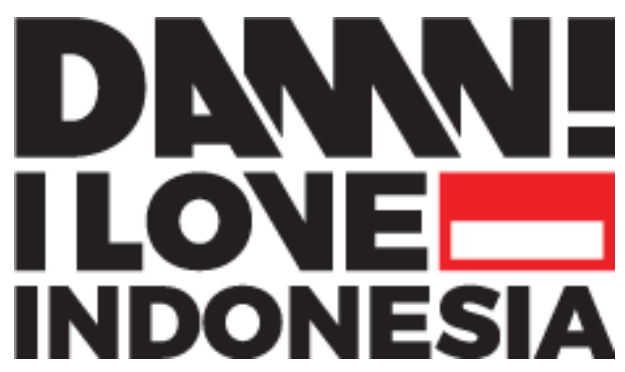

Gambar 1. Logo Damn! I Love Indonesia

Sumber: www.damniloveindonesia.com

Damn! I Love Indonesia merupakan salah satu Fashion brand yang hadir dengan konsep nasionalisme yang di bentuk oleh PT. Dinamika Anak Muda Nasional dengan segmentasi anak muda. Didirikan oleh Daniel Mananta sebagai bentuk apresiasi terhadap tanah airnya, Indonesia. Daniel memperkenalkan label PT. Dinamika Anak Muda Nasional (Damn! I Love Indonesia) sebagai bentuk usaha untuk berkontribusi menjadi salah satu bagian dalam konservasi budaya Indonesia. Daniel memperkenalkan merek tersebut untuk menginspirasi generasi muda Indonesia untuk lebih sadar dan bisa dibanggakan dari warisan, budaya, dan sejarah bangsa Indonesia. PT. Dinamika Anak Muda Nasional (Damn! I Love Indonesia) berupaya menginspirasi anak-anak muda Indonesia agar semakin mencintai budaya dan sejarah Indonesia dalam balutan gaya hidup Urban. (sumber : http://www.damniloveindonesia.com/about-us)

Telah melebarkan brand sampai kepada Damn! I Love ASEAN, PT. Dinamika Anak Muda Nasional terus berinovasi dengan memunculkan logo terbaru dan tagline terbaru "Inspired To Inspire The Nation" pada tahun 2018. Oleh karena itu, inovasi tersebut diharapkan dapat mengambil hati para pencinta fashion khususnya anak muda Indonesia dengan rasa nasionalisme yang ada. 


\section{National Conference of Creative Industry: \\ Sustainable Tourism Industry for Economic Development}

Universitas Bunda Mulia, Jakarta, 5-6 September 2018

ISSN No: 2622-7436

Grerakan yang dibuat oleh Daniel Mananta selaku founder dan CEO dari PT. Dinamika Anak Muda Nasional menarik peningkatan citra Indonesia untuk mejadi salah satu aspek sektor Pariwisata menjadi salah satu daya tarik kebangkitan ekonomi suatu negara. Rani (2014 : 413) menyampaikan bahwa adanya pariwisata yang menjadi lahan penerimaan devisa negara atau pendapatan daerah yang menjadi efek domino.

Kehadiran teknologi website membuat korporat seperti PT. Dinamika Anak Muda Nasional memanfaatkan kesempatan untuk mempromosikan brand serta membentuk wadah untuk melakukan penjualan secara online dengan membuka $e$-store www.damniloveindonesia.com. Banyak fitur-fitur yang menarik salah satunya spotlight yang digunakan public relations korporat untuk memberikan informasi dalam bentuk berita terkini yang mengugah para pembaca untuk melihat kegiatan korporat secara berkala.

Penelitian ini melihat identitas nasionalisme dikonstruksi sebagai identitas fashion brand melalu website www.damniloveindonesia.com melalui fitur spotlight yang berisi berita perkembangan korporat yang kemudian bisa diterima oleh khalayak, kemudian produk ini dapat mewakili produk lokal menjadi ambassador pariwisata nasional dan menjadi salah satu penyumbang kebangkitan ekonomi di Indonesia. Peneliti mencoba menggunakan metode analisis framing Zhongdang Pan dan Gerald M. Kosicki, kemudian menggunakan Teori Manajemen Kesan sebagai prespektif teori dalam penelitian ini.

\section{TINJAUAN LITERATUR}

Teori manajemen kesan atau sering disebut Impression management (Kreitner \& Kinichi: 2005) dalam Saputro dkk, (2017:60) merupakan suatu proses dimana seseorang berusaha untuk mengendalikan atau memanipulasi reaksi orang lain terhadap citra diri orang tersebut maupun ide-idenya. Impression management dapat dilakukan dengan mengubah berbagai gaya hidup pelaku komunikasi seperti cara berpakaian, mematuhi norma dan peraturan di tempat dia berada, mengambil nama atas pekerjaan orang lain, cara berbicara, cara berjalan dan yang lainnya.

Goffman menjelaskan bahwa ketika seseorang berkomunikasi selalu ada usaha untuk menghasilkan gambar diri yang diterima oleh orang lain, sehingga adanya aktualisasi diri. Ia menyebut upaya itu sebagai "pengelolaan kesan", yang merupakan teknik yang digunakan pelaku komunikasi untuk memupuk kesan dalam situasi dengan tujuan tertentu. Menurut Goffman kita "mengelola" informasi yang kita berikan kepada orang lain. Kita mengendalikan presepsi yang akan ditimbulkan melalui busana, penampilan, dan kebiasaan kita kepada orang lain supaya orang lain memandang kita sebagai orang yang ingin kita tunjukan. Sebagaimana seorang aktor yang memainkan peran, mengasumsikan karakter, dan bermain melalui adegan-adegan ketika terlibat dalam interaksi dengan orang lain (Ariani, 2016: 354).

Hayati, 2014 dalam (Clat-worthy \& Jones, 2001), menjelaskan manajemen kesan yang dilakukan korporat yang juga telah diidentifikasi sebagai sesuatu hal yang terjadi dalam pengaturan dari individu pengambil kebijakan, pihak manajemen dan perwakilan organisasi membuat serta menyajikan informasi, sehingga dapat memengaruhi sikap, pendapat, dan perilaku pengguna informasi tersebut. Dalam konteks pelaporan perusahaan, manajemen 
kesan dianggap sebagai usaha untuk mengontrol dan memanipulasi kesan yang disampaikan kepada setiap orang yang mengakses informasi.

Manajemen kesan juga diibaratkan seperti bangunan yang merepresentasikan penampilan dan pemeliharaan identitas sosial selama interaksi. Beberapa peneliti menggunakan konsep diri public (public self) atau diri sosial (sosial self) untuk membedakan identitas sosial dari kehidupan pribadi. Setiap individu, kita diatur oleh berbagai keistimewaan seperti kebiasaan, perilaku yang sopan, keyakinan, sikap, nilai, kemampuan, kebutuhan, ketertarikan, sejarah keluarga, dan sebagainya. Ketika berinteraksi dengan pihak lain, kita tidak dapat menampilkan seluruh aspek dalam kehidupan pribadi kita. Oleh karenanya kita akan memilih karakter-karakter dari matriks perilaku dan psikologis kita yang akan mempresentasikan diri yang harus kita jalani dalam kondisi tersebut (Lailiyah, 2016: 104).

Penelitian ini menggunakan Teori Manajamen Kesan yang direpresentasikan melalui generasi muda yang menjadi segmentasi dari Damn! I Love Indonesia. Setiap generasi muda dalam hal ini mampu membuat dirinya menimbulkan kesan anak muda nasionalis dengan menggunakan produk Damn! I Love Indonesia. Selain itu, hal tersebut diharapkan oleh korporat untuk menjadi kesempatan yang baik dengan melakukan Corporate Social Responsibility (CSR) yang merupakan tanggung jawab sosial Damn! I Love Indonesia menjadi sarana untuk membakar semangat anak muda melalui upaya menunjukkan jiwa nasionalismenya terhadap bangsa melalui gaya fashion mereka.

Indonesia mempunyai kewajiban perusahaan untuk melakukan komunikasi CSR telah diatur dalam UU No.40 Tahun 2007 pasal 66 ayat (2) tentang perseroan terbatas. Dalam peraturan tersebut dinyatakan bahwa perusahaan yang mengelola sumber daya alam diwajibkan untuk mengkomunikasikan aktivitas CSR-nya melalui media laporan tahunan (Putra, dkk, 2015:23). Rusdianto (2013: 57) menjelaskan bahwa banyak media yang dapat dipilih perusahaan dalam komunikasi CSR, yaitu: media yang bersifat internal (Public Relations, Laporan CSR, majalah internal, website, media sosial dan lainnya) dan media yang bersifat eksternal (media massa, dan word of mouth).

Perusahaan yang mempertahankan praktek bisnis berkelanjutan, harus secara serius mengambil peluang yang ditawarkan oleh new media, yaitu media komunikasi CSR melalui website. Website memenuhi kriteria sebagai pelengkap komunikasi CSR melalui media tercetak yang efektif di tengah-tengah tuntutan kebutuhan informasi stakeholders yang beragam sifatnya dan segera tersedia (Nwagbara dan Reid, 2013: 411).

Damn! I Love Indonesia mengambil momen Asian Games 2018 untuk melakukan CSR dengan mewujudkan promosi pariwisata Indonesia melalui nasionalisme dalam fashion terdapat beberapa pengemasan identitas korporat dan publisitas CSR yang ditempuh melalu www.damniloveindonesia.com agar selaras dengan konsep cyber CSR, dimana website korporat menjadi media publisitasnya.

Cyber CSR adalah menjadi salah satu cara korporat untuk menanggapi perkembangan teknologi dengan melakukan publisitas CSR dalam website korporat. Hidayat dalam bukunya yang berjudul Media Public Relations (2014: 95), cyber CSR didefinisikan sebagai strategi komunikasi perusahaan dalam penyampaian informasi terkait CSR perusahaan kepada stakeholders melalui teknologi online. 


\section{National Conference of Creative Industry: \\ Sustainable Tourism Industry for Economic Development}

Universitas Bunda Mulia, Jakarta, 5-6 September 2018

ISSN No: 2622-7436

Cyber CSR disimpulkan dari beberapa definisi adalah upaya perusahaan dalam menyampaikan pesan dan mendistribusikan pesan yang telah dirancang terkait komitmen, kebijakan, program dan kinerja perusahaan dalam pilar ekonomi, lingkungan, serta sosial kepada para stakeholders perusahaandengan menggunakan media komunikasi berbasis teknologi internet salah satunya website sebagai sarana publisitasnya (Putra dkk, 2015).

\section{METODE PENELITIAN}

Penelitian ini menggunakan pendekatan penelitian kualitatif, dimana merupakan pendekatan penelitian yang berlandaskan pada tulisan maupun secara lisan dari tindakan bisa yang dilihat. Peneliti menggunakan pendekatan kualitatif dengan pendekatan deskriptif dikarenakan peneliti ingin menganalisa fenomena public relations dalan mengkonstruksikan kejadian yang terjadi di korporat yang dibentuk menjadi berita (Moleong , 2007: 4). Penelitian ini juga menggunakan paradigma konstruktivis untuk melihat makna yang dibangun pada identitas nasionalisme dalam fashion.

Framing adalah sebuah cara bagaimana peristiwa disajikan oleh media. Penyajian tersebut dilakukan dengan menekankan bagian tertentu, menonjolkan aspek tertentu dan membesarkan cara bercerita tertentu dari suatu realitas. Media menghubungkan dan menonjolkan peristiwa, sehingga makna dari peristiwa tersebut lebih mudah diingat oleh khalayak. Oleh karena itu, seperti yang dikatakan Frank D. Durham, framing membuat dunia lebih diketahui dan lebih dimengerti (Anggoro, 2014).

Peneliti menggunakan analisis framing milik Zhongdang Pan dan Gerald M. Kosicki atau disingkat Pan dan Kosicki. Putri, 2012 dalam Sobur (2009: 175-176), dalam Framing Pan dan Kosicki proses analisis dibingkai melalui perangkat penelusuran yang dibagi dalam empat struktur besar, yaitu Sintaksis, Skrip, Tematik, dan Retoris. Struktur sintaksis berhubungan dengan cara wartawan menyusun peristiwa, pernyataan, opini, kutipan, pengamatan atas peristiwa ke dalam bentuk susunan kisah berita. Struktur skrip melihat bagaimana strategi bercerita atau bertutur yang dipakai wartawan dalam mengemas peristiwa. Struktur tematik berhubungan dengan cara wartawan mengungkapkan pandangannya atas peristiwa ke dalam proposisi, kalimat, atau hubungan antar kalimat yang membentuk teks secara keseluruhan. Struktur retoris berhubungan dengan cara wartawan menekankan arti tertentu. Dengan kata lain, struktur retoris melihat pemakaian pilihan kata, idiom, grafik, gambar, yang juga dipakai guna memberi penekanan pada arti tertentu. Peneliti menggunakan metode Framing Pan dan Kosicki untuk membelah dan melihat kualitas artikel press release yang menjadi sarana cyber CSR yang dilakukan oleh produk Damn! I Love Indonesia.

\section{HASIL PENELITIAN DAN PEMBAHASAN}

Nama Damn! I Love Indonesia merupakan fashion brand dari PT. Dinamika Anak Muda Nasional, diluncurkan sejak tanggal 28 Oktober 2008 dengan tokonya yang pertama berlokasi di FX Lifestyle Center lantai 6. Sejak saat itu perusahaan terus berkembang dan sekarang sudah memiliki sembilan toko mulai dari Jakarta (Kota Kasablanka, Grand Indonesia, Pondok Indah Mall, Central Park Mall), Surabaya (Grand City Surabaya, Tunjungan Plaza), Makassar (Panakukang Mall), Bali (Beachwalk Shopping Center), dan Tangerang (Bandara Internasional Soekarno Hatta). Selanjutnya, Damn! I Love Indonesia melebarkan lagi ranah 
bisnisnya dengan mengambil pasar online melalui www.damiloveindonesia.com. Dengan hadirnya pejualan dalam bentuk website membuat pemanfaatan teknologi dalam melakukan banyak kegiatan promosi termasuk informasi identitas merk kepada khalayak, salah satu kegiatan yang dilakukan dengan menggunakan cyber CSR.

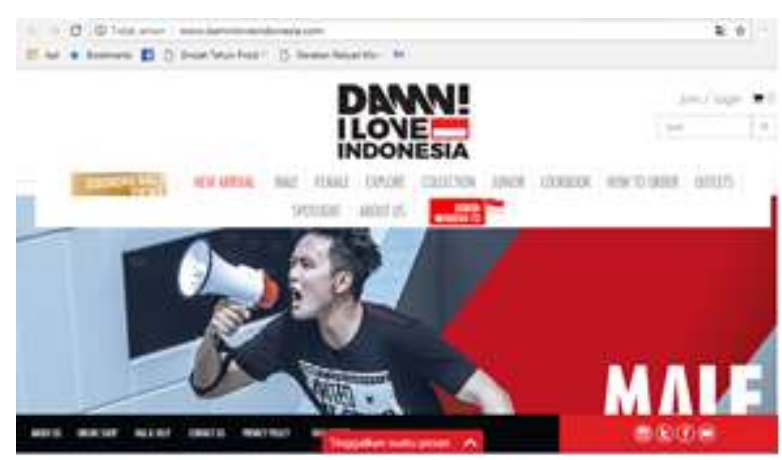

Gambar 2. Tampilan Website

Sumber: www.damniloveindonesia.com

Damn! I Love Indonesia dalam menyambut perayaan satu dekade dan menyambut program pemerintah yang menyelenggarakan Asian Games 2018 membuat program CSR dengan mengeluarkan logo, tagline dan signature series yang berhubungan dengan perayaan pesta olahraga terbesar se-Asia. Selanjutnya, peneliti melihat kualitas press release yang diterbitkan dalam www.damniloveindonesia.com dalam menginformasikan mengenai CSR melalui website.

Analisis sintaksis, merupakan susunan kata yang baik yang biasanya meliputi judul, lead, headline, latar informasi, penutup dalam kesatuan teks (Eriyanto, 2009). Sintaksis yang dikemukakan oleh Damn! I Love Indonesia ditampilkan melalui website www.damniloveindonesia.com dalam bentuk press realese yang dikeluarkan.

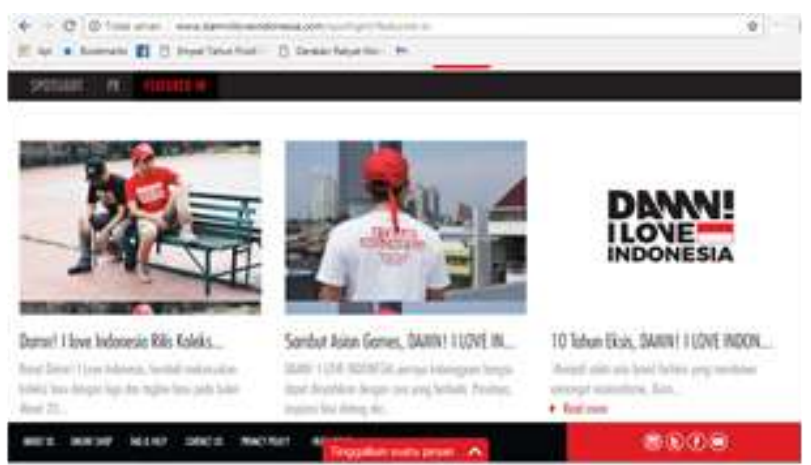

Gambar 3. Tampilan Spotlight Website

Sumber: www.damniloveindonesia.com

Judul artikel dalam website ini "Damn! New Logo \& Signature Series" secara jelas menunjukkan adanya re-branding yang dilakukan oleh Damn! I Love Indonesia berupa keluaran logo baru, tagline baru, dan keluaran produk terbaru, sehingga terlihat adanya 


\title{
National Conference of Creative Industry: \\ Sustainable Tourism Industry for Economic Development
}

Universitas Bunda Mulia, Jakarta, 5-6 September 2018

ISSN No: 2622-7436

komitmen Damn! I Love Indonesia untuk terus berinovasi dengan waktu. Terlihat bahwa judul tesebut merepresentasikan dalam rangka satu dekade Damn! I Love Indonesia, sehingga citra produk yang terus berkualitas yang selalu hadir untuk segmentasi anak muda Indonesia. Pada bagian lead Damn! I Love Indonesia ingin menangkap momen satu dekade persepsi yang semakin baik.

\begin{abstract}
Jakarta, 07 Maret 2018 - Hampir satu dekade sudah DAMN! I LOVE INDONESIA, konsisten menjalankan visi misinya untuk menyebarkan rasa cinta serta bangga-nya para generasi muda terhadap tanah air. Agar tetap terus relevan dan mendapatkan persepsi yang semakin baik, DAMN! I LOVE INDONESIA me-refresh tampilan desain komunikasi dan produknya, dengan meluncurkan LOGO dan tagline baru serta produk Signature Series baru di bulan Maret 2018.
\end{abstract}

Mengenai konsepsi mengenai brand, presepsi merupakan hal pertama yang harus ditangkap oleh korporat untuk mengambil simpatik calon konsumen. Ketika ada presepsi yang baik mengenai Damn! I Love Indonesia yang selalu konsisten untuk mewarnai fashion style anak muda, sehingga nampak gerakan yang ditujukan kepada setiap individu muda menampakkan kesan yang baik, sehingga menempelnya brand nasionalis terhadap setiap pribadi untuk lebih pemantik citra Indonesia sekaligus promosi pariwisata nasional. Kutipan lead di atas juga secara tidak langsung menempatkan Damn! I Love Indonesia dalam tampilan non verbal baru melalui desain simbolik dengan mengolah tiga aspek sekaligus, mulai dari pembuatan logo terbaru, tagline terbaru, dan signature series terbaru di bulan Maret 2018.

Frame dari Damn! I Love Indonesia pada press release di website www.damniloveindonesia .com memicu penggalian akan alasan sebagai analisis skrip Pan dan Kosicki atas apa yang dilakukan Damn! I Love Indonesia melaui penguraian 5W+1H:

Pertama, melihat yang dilakukan oleh Damn! I Love Indonesia dalam rangka merayakan satu dekade sebagai "what". Damn! I Love Indonesia berusaha untuk meningkatkan mengenai presepsi anak muda mengenai gaya kekinian yang direpresentasikan melalui fashion dengan cara menyegarkan kembali identitas merk melalui pergantian logo, taglline, dan signature series untuk produk yang lebih sesuai.

Kedua, menjadi alasan perayaan satu dekade dilakukan dengan adanya perubahan sebagai "Why". Tahun 2018 merupakan tahun kebesaran negara Indonesia, dimana seluruh mata negara Asia tertuju dengan adanya perhelatan pesta olahraga terbesar, yaitu Asian Games 2018 sehingga mendorong Damn! I Love Indonesia untuk melakukan inovasi produk yang lebih dinamis, hype, terpecaya, dan inspiratif.

Ketiga, memperlihatkan segmentasi Damn! I Love Indonesia kali ini sebagai "Who". Semejak berdiri dari tahun 2018 Damn! I Love Indonesia berkomitmen untuk menjangkau generasi muda khusunya wilayah urban untuk menjadi agen perubahan dengan tumbuhnya rasa naionalisme yaitu kebanggaan atas negeri sendiri untuk meningkatkan citra negara yang berkualitas.

“DAMN!I LOVE INDONESIA sangat excited dan siap menyambut Asian Games 2018, dan kami akan mengeluarkan produk yang dapat membuat semua yang nonton Asian Games bisa mendukung Tim Indonesia, dan menyiapkan design produk yang diberi sentuhan kata-kata 


\title{
National Conference of Creative Industry: \\ Sustainable Tourism Industry for Economic Development
}

Universitas Bunda Mulia, Jakarta, 5-6 September 2018

ISSN No: 2622-7436

\begin{abstract}
yang menginspirasi seperti \#TeamIndonesia, \#TeamGaruda, dan kata-kata penyemangat inspiratif lainnya. DAMN!I LOVE INDONESIA juga sangat optimis dengan logo dan tagline baru ini, inspired to inspire the nation, kami berharap anak muda Indonesia maupun Asia, dapat termotivasi untuk mempromosikan Indonesia kepada keluarga dan teman-temannya dimanapun mereka berada melalui design design kami" tutur, Daniel Mananta selaku Founder \& CEO DAMN! I LOVE INDONESIA.
\end{abstract}

Keempat, dimana representasi nasionalisme fashion brand Damn! I Love Indonesia dapat temukan sebagai "Where". Hal ini dikaitkan dengan manajemen kesan yang terlihat dari produk fashion Damn! I Love Indonesia yang merepresentasikan penampilan dan pemeliharaan identitas sosial yang cinta akan Indonesia yang direpresentasikan oleh setiap generasi muda melalui simbol yang terkadung dalam setiap produk ini dimanapun kaum muda berada.

Kelima, memperlihatkan momentum satu dekade ini akan dilaksanakan sebagai "When"). Sepanjang tahun 2018 menjadi momen waktu yang sangat penting bagi Damn! I Love Indonesia mulai dari Asian Games 2018 dan perayaan satu dekade yang akan dilaksanakan oktober mendatang.

Keenam, bagaimana naionalisme dalam fashion dapat berjalan sebagai "How". Damn! I Love Indonesia berharap melalui nasionalisme fashion anak muda bisa berjalan dengan cara mempromosikan Indonesia kepada keluarga dan teman-temannya dimanapun mereka berada melalui design-design produk terbaru.

Struktur tematik dalam kandungan press release di situs www.damniloveindonesia.com menggunakan kekayaan dan kearifan lokal Indonesia yang kayak akan sejarah, bahasa, budaya dan kuliner yang Indah sebagai simbol bahwa produk Damn! I Love Indonesia identik dengan identitas nasionalisme yang ada melalui bentuk fashion lifesyle yang dinamis, keren, anak muda, kekinian, sehingga Damn! I Love Indonesia dapat diterima di mancanegara. Salah satu buktinya, yaitu ekspansi Damn! I Love Indonesia yang sudah memasarkan produknya sampai ke pasar ASEAN.

\footnotetext{
Kebanggaan DAMN! I LOVE INDONESIA terhadap tanah airnya terinspirasi dari keanekaragaman budaya dan alam yang ada di Indonesia, mulai dari sejarahnya, pahlawanpahlawannya, bahasa, budaya, kuliner dan alam yang indah, yang dituangkan menjadi fashion lifestyle yang berani, dinamis, keren, anak muda, kekinian dan dapat diterima semua masyarakat Indonesia maupun mancanegara. Maka, diluncurkanlah produk baru, Signature series yang lebih sporty dan casual, di design untuk program road to menuju perhelatan akbar Asian Games 2018 pada bulan Agustus mendatang.
}

Struktur Retorik, mengambarkan adanya pilihan gaya atau kata yang ditonjolkan oleh Damn! I Love Indonesia. Perangkat retoris ini digunakan untuk membuat citra dan kemenonjolan pada sisi tertentu yang meningkatkan gambaran yang diinginkan dalam suatu cerita tanpa menghilangkan kebenaran (Eriyanto, 2009). Retorik dalam artikel press release ini menampilkan tagline terbaru dalam rangka membuat re-branding yang terbaru yaitu:

\section{DAMN! I LOVE INDONESIA is... INSPIRED TO INSPIRE THE NATION.}

Tagline terebut seakan membuat nation branding dimana terdapat potensi besar untuk pariwisata Indonesia lebih dikenal melalu produk fashion serta didukung oleh segmentasi anak muda yang lebih enerjik, berani, sangat memperhatikan penampilan dalam bergaul. 
"DAMN!I LOVE INDONESIA sangat excited dan siap menyambut Asian Games 2018, dan kami akan mengeluarkan produk yang dapat membuat semua yang nonton Asian Games bisa mendukung Tim Indonesia, dan menyiapkan design produk yang diberi sentuhan kata-kata yang menginspirasi seperti \#TeamIndonesia, \#TeamGaruda, dan kata-kata penyemangat inspiratif lainnya.

Hadirnya momen Asian Games 2018 menjadi momen yang cocok sehingga adapula tagline yang disesuaikan dengan pegelaran kegiatan kompetisi olahraga terbesar se-Asia dan didukung oleh setiap design yang ditampilkan dalam bentuk gambar model pada website Damn! I Love Indonesia.

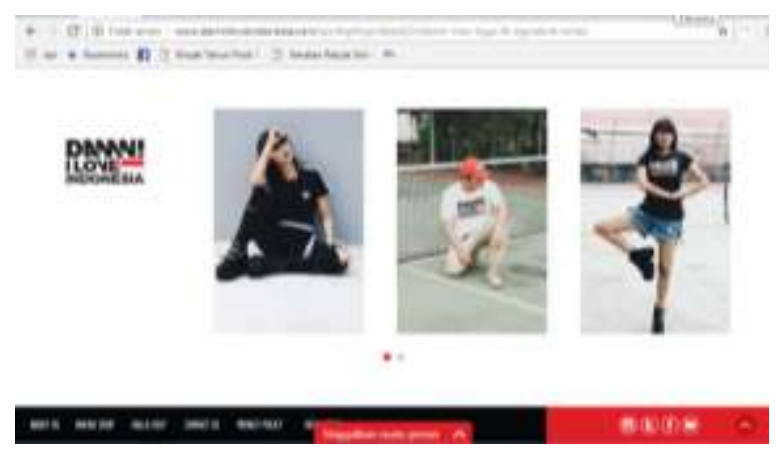

Gambar 4. Retorika Berupa Gambar 1

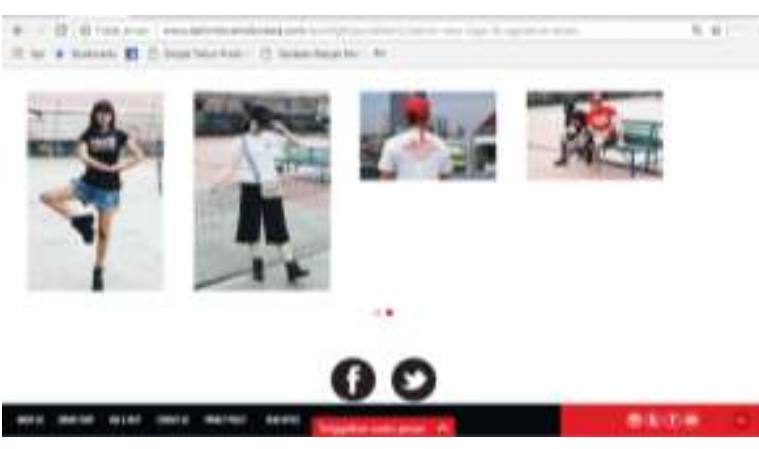

Gambar 5. Retorika Berupa Gambar 2

Sumber: www.damniloveindonesia.com

\section{KESIMPULAN DAN IMPLIKASI}

Damn! I Love Indonesia telah berevolusi dan melakukan perubahan melalui banyak hal, mulai dari mempelebar jangkauan pasar melalui penjualan online melalui website www.damniloveindonesia.com hingga menggunakan website sebagai sarana publisitas informasi CSR atau lebih dikenal dengan istilah cyber CSR.

Trisnawati (2011: 46) mengambarkan fashion saat ini telah mengalami perubahan nilai yang awalnya menjadi kebutuhan pokok untuk menutupi bagian tubuh, sekarang lebih memiliki makna tanda (sign value), dimana busana dapat bermakna saat dikorelasikan dengan nilainilai sosial yang ada, sehingga erat dengan yang namanya citra yang dimunculkan melalui komunikasi simbolik (non verbal). Pada skrip, khususnya analisis who secara jelas Damn! I Love Indonesia melalui generasi muda berharap bisa ambassador bukan hanya bagi korporat tetapi bagi potensi pariwisata Indonesia dengan menampilakan sisi nilai nasionalis dalam fashion.

Sisi lain, melalui analisis framing yang dilakukan yang menunjukan perubahan identitas yang dilakukan oleh Damn! I Love Indonesia dalam rangka untuk lebih konsisten untuk berkontribusi lebih jauh menampilkan rasa nasionalisme dalam fashion dengan memanfaatkan momen Asian Games 2018 dan kemudian secara retorika adanya penonjolan dalam segi tagline dan keluaran jenis produk terbaru yang ditampilkan melalui gambar dalam 
isi press release melalui www.damniloveindonesia.com dengan momen kompetisi olah raga terbesar se-Asia tersebut.

Rekomendasi dalam penelitian ini menunjukkan bahwa untuk mengembangkan ke gerakan dalam memantik citra negara melalui pariwisata dapat melalui berbagai hal, termasuk melalui tren fashion masa kini. Korporat diharapkan dapat mewujudkan program CSR kepada lingkungan sekitar bahkan negara dengan cara yang sederhana seperti menunjukkan visi atau identitas korporat yang selaras dengan visi pemerintah.

\section{DAFTAR PUSTAKA}

Anggoro, Ayub Dwi . 2014. "Media, Politik, dan Kekuasaan (Analisis Framing Model Robert N. Entman tentang pemberitaan hasil pemilihan Presiden 9 Juli 2014 di TV One dan Metro TV )" . Jurnal Aristo, Vol.2 No. 2 dalam http://journal.umpo.ac.id/index.php/aristo/article/view/16/275

Ariani, Trigartanti .2016. "Impression Management Seorang Selebgram sebagai Eksistensi Diri melalui Media Sosial Instagram”. Prosiding Hubungan Masyarakat, Vol.2, No.1 dalam http://karyailmiah.unisba.ac.id/index.php/humas/article/viewFile/3160/pdf

Eriyanto. 2009. Analisis Framing. Yogyakarta: Lkis Yogyakarta

Hayati, Dian Indah .2016. "Pengaruh Good Corporate Governance (GCG) Terhadap Manajemen Kesan (Studi Empiris Pada Perusahaan Manufaktur yang Terdaftar di Bursa Efek Indonesia Tahun 2014)" Jurnal Akuntansi, Vol 4, No.1 dalam http://ejournal.unp.ac.id/students/index.php/akt/article/view/2354/1863

Hidayat, Dasrun. (2014). Media Public Relations: Pendekatan Studi Kasus Cyber Public Relations Sebagai Metode Kerja PR Digital. Yogyakarta: Graha Ilmu.

Lailiyah, Nuriyatul .2016. "Presentasi Diri Netizen dalam Konstruksi Identitas di Media Sosial dan Kehidupan Nyata" Jurnal Ilmu Sosial, Vol. 15, No. 2, Hal. 103-110 dalam https://ejournal.undip.ac.id/index.php/ilmusos/article/viewFile/13618/10266

Lexy, Moleong. J. 2007. Metode Penelitian Kualitatif. Bandung: Remaja Rosdakarya

Putra, Saputri .2015. "Komunikasi Cyber CSR: Analisis Isi pada Official Website PT Bank Pembangunan Daerah Jawa Barat dan Banten” Jurnal Channel, Vol. 3, No. 2, hal. 17-39 dalam http://journal.uad.ac.id/index.php/CHANNEL/article/view/3271/1852

Putri, Ayu Nur Irwinesia .2012. “Analisis Framing Berita Demonstrasi Mahasiswa Semarang Terkait Harga BBM Pada Tv Borobudur”. Jurnal The Messenger, Vol. IV, No. 1, dalam http://journals.usm.ac.id/index.php/the-messenger/article/view/156/128

Rani, Deddy Prasetya Maha . 2014. "PENGEMBANGAN POTENSI PARIWISATA Kabupaten Sumenep, Madura, Jawa Timur (Studi Kasus: Pantai Lombang)". Jjurnal Politik Muda, Vol. 3, No. 3 dalam 


\section{National Conference of Creative Industry: \\ Sustainable Tourism Industry for Economic Development}

Universitas Bunda Mulia, Jakarta, 5-6 September 2018

ISSN No: 2622-7436

http://journal.unair.ac.id/JPM@ @engembangan-potensi-pariwisata-kabupaten-

sumenep,-madura,-jawa-timur-(studi-kasus-article-8100-media-80-category-8.html

Rusdianto, Ujang. (2013). CSR Communications: A Framework of PR Practicioner. Yogyakarta: Graha Ilmu

Saputro, Diniati .2017. "Manajemen Kesan Pengguna Media Sosial Instagram Dalam Mengeksistensikan Pancasila" Jurnal Wacana, Vol. 16, No. 1, hlm. 57 - 83 dalam http://journal.moestopo.ac.id/index.php/wacana/article/view/12/pdf

Trisnawati, Tri Yulia .2011. "Fashion sebagai Bentuk Ekspresi Diri dalam Komunikasi “. Jurnal The Messenger, Vol. III, No. 1 dalam http://journals.usm.ac.id/index.php/themessenger/article/viewFile/268/170

\section{BIODATA}

\section{Biografi singkat Penulis Pertama}

Joshua Fernando, pria kelahiran Jakarta, 7 Maret 1996. Meraih gelar Sarjana Ilmu Komunikasi pada tahun 2017 di Universitas Bunda Mulia. Saat ini sedang melanjutkan studi sebagai mahasiswa Magister Ilmu Komunikasi Universitas Bunda Mulia, Jakarta. Memiliki ketertarikan menjadi peneliti muda dengan melakukan penelitian khususnya di bidang komunikasi kajian pembangunan dan kesetaraan gender khususnya partisipasi anak dalam pembangunan daerah. Salah satu kontribusi dibidang pembangunan adalah dengan menjadi delegasi mewakili Indonesia dalam United Nations Human Rights Council yaitu simulasi sidang PBB di acara Asia Youth International Model United Nations 2017, Kuala Lumpur, Malaysia dan bergabunng dalam General Asembly 2 council "Advecment of Women" di United Nations for Model United Nations 2018, Bangkok, Thailand

\section{Biografi singkat Penulis Kedua}

Rustono Farady Marta atau yang akrab dipanggil "Frad" ini memperoleh gelar Sarjana pada Program Studi Ilmu Komunikasi di Universitas 17 Agustus 1945 Surabaya, kemudian melanjutkan studi jenjang S2 pada Program Magister Media \& Komunikasi (MedKom) di Universitas Airlangga Surabaya. Pencapaian puncak studi dituntaskan dari Program Doktor Ilmu Komunikasi Universitas Indonesia pada tahun 2017, sembari meluncurkan buku perdana yang ditulis bersama Ibu Supina, S.ST.Par, M.Par., MM. in ITM. dengan judul "GEGAR BUDAYA NUSANTARA: Implementasi Komunikasi Pariwisata Lintas Kultural". Kini aktifitas sehari-hari Frad mengajar di Universitas Bunda Mulia Jakarta pada tiga program studi, antara lain: Sarjana Ilmu Komunikasi, Bachelor Degree of Hospitality and Tourism, dan Magister Ilmu Komunikasi serta dipercaya mengampu asistensi Prof. Dr. phil. Hana Rochani Guntasari Panggabean, Psi. pada Program Pascasarjana Magister dan Doktor Psikologi Universitas Katolik Indonesia Atma Jaya Jakarta. Di sisi lain, prestasi di bidang riset yang pernah diukir adalah meraih gelar Terbaik III pada Indonesia Media Research Awards and Summit (IMRAS) selama dua tahun berturut-turut untuk kategori social media (2014) dan kategori online media (2015). Pada tahun berikutnya berhasil memperoleh Beasiswa Menulis Ilmiah Populer 2016 oleh Tempo Institute dan masuk dalam jajaran 10 
terbaik nasional untuk Kompetisi Proposal Riset Anti-Korupsi Jurnal Integritas 2018 yang diadakan oleh Komisi Pemberantasan Korupsi. 